\title{
Growth performance and nitrogen use efficiency of two Populus hybrid clones $(P$. nigra $\times$ P. maximowiczii and $P$. trichocarpa $\times P$. maximo- wiczii) in relation to soil depth in a young plantation
}

\author{
Dejuan Euring ${ }^{(1)}$, \\ Sam Ayegbeni ${ }^{(1)}$, \\ Martin Jansen (2), \\ Jing Tu ${ }^{(1-3)}$, \\ Clessio Gomes Da Silva ${ }^{(1)}$, \\ Andrea Polle ${ }^{(1)}$
}

\section{Introduction}

Woody biomass is considered as a sustainable alternative source of energy for fossil fuels (Pleguezuelo et al. 2015). Short rotation woody crops such as poplar trees (Populus spp.) are well suited for woody biomass production because they are highly productive and can be managed using agronomic techniques (Kauter et al. 2003). To avoid competition for fertile land with food production, poplar plantations are expected to be established on margina land which is less suitable for agriculture because of limited water and nutrient avail ability (Shortall 2013). Since the productiv ity of a poplar plantation depends on the proper selection of genotypes (Zalesny et al. 2011), research is needed to identify poplar cultivars with high survival rates, high biomass productivity and high disease resistance for cultivation on marginal soil (Polle et al. 2013).

\begin{abstract}
It is a challenge to produce woody crops on marginal land. The goal of this study was to examine growth responses and nitrogen use efficiency of different poplar species on shallow soil. Typical biomass poplar clones of Max1 ( $P$. nigra $\times$ P. maximowiczii) and $\mathrm{H} 275$ ( $P$. trichocarpa $\times P$. maximowiczii) were planted on a marginal site where a gradient in soil depth was present. The growth, biomass production, and nitrogen uptake rate as well as nitrogen use efficiency of Max1 and H275 were determined for three consecutive years. Both poplar clones showed decreased growth and biomass production in the shallow soil. Max1 showed better adaptation to shallow soil with higher survival rate and more biomass production than H275. Max1 had lower nitrogen use efficiency on shallow soil than $\mathrm{H} 275$. The results suggest that higher nitrogen uptake of poplar species might be an important adaptation to maintain productivity under unfavorable soil conditions.
\end{abstract}

\section{Keywords: Biomass, Nitrogen Use Efficiency, Poplar, Shallow Soil}

Shallow soil with limited rooting depth, low drainage and high stone content are typical features of marginal land (Jiang et al. 2014). Rooting depth is an important determinant for the successful establishment and production of woody biomass (Burgess et al. 2015). N storage and cycling are vital processes for growth, adaptation and productivity of poplar trees (Millard \& Grelet 2010). N storage and remobilization are particularly important to meet the $\mathrm{N}$ demand of forest trees for continuous growth (Rennenberg et al. 2010). Poplar species differ in the way they take up and assimilate $\mathrm{N}$ (Luo et al. 2013, Gan et al. 2015), which may impact their competitive ability for soil nutrients and resistance to environmental stresses (Castro-Rodríguez et al. 2015, Luo et al. 2015, Molina-Rueda \& Kirby 2015). Several studies have focused on identifying and quantifying the best management practices to successfully es-

(1) Büsgen-Institut, Abteilung Forstbotanik und Baumphysiologie, Georg-August Universität, Büsgenweg 2, D-37077 Göttingen (Germany); (2) Büsgen-Institut, Abteilung Ökopedologie der gemäßigten Zonen, Georg-August Universität, Büsgenweg 2, D-37077 Göttingen (Germany); (3) College of Environmental Science and Engineering, Southwest Forestry University, No. 300 Bailongsi, 650224, Kunming City, Yunnan Province (P. R. China)

@ Dejuan Euring (dning@gwdg.de)

Received: Feb 18, 2016 - Accepted: Jul 19, 2016

Citation: Euring D, Ayegbeni S, Jansen M, Tu J, Gomes Da Silva C, Polle A (2016). Growth performance and nitrogen use efficiency of two Populus hybrid clones ( $P$. nigra $\times P$. maximowiczii and $P$. trichocarpa $\times P$. maximowiczii) in relation to soil depth in a young plantation. iForest 9: 847-854. - doi: 10.3832/ifor2016-009 [online 2016-09-22]

Communicated by: Gianfranco Minotta tablish hybrid poplar plantations under different nitrogen regimes (Lee \& Jose 2003, Euring et al. 2012). However, there is little information on how different poplar species cope with shallow soil and whether shallow soil affects nitrogen use efficiency. In this study, two different poplar clones, Max1 (P. nigra $\times$ P. maximowiczii) and $\mathrm{H} 275$ ( $P$. trichocarpa $\times P$. maximowiczii), were selected to assess the productivity and nitrogen use efficiency on shallow soil. Max1 and $\mathrm{H}_{2} 75$ are both commercial poplar clones often used in poplar plantations (Bungart \& Hüttl 2004, Nielsen et al. 2014). Here we expected that both poplar clones showed decreased growth and biomass production on shallow than on deep soil. Since Max1 was found to be well growing under drought conditions (Schildbach et al. 2012), we hypothesized that (i) clonal differences in adaptation to shallow soil do exist, and that (ii) the clone with higher nitrogen uptake has a greater productivity on shallow soil compared to the clone with lower nitrogen uptake.

To test these hypotheses, a plantation with Max1 and $\mathrm{H}_{2} 75$ was established on shallow and deep soil, and the performance of both clones was studied for 3 years.

\section{Material and methods}

Plant material and site description

Cuttings of fast growing hybrid poplars Max 1 (P. nigra $\times$ P. maximowiczii) and $\mathrm{H} 275$ (P. trichocarpa $\times P$. maximowiczii) $21 \mathrm{~cm}$ in length, were planted at the end of March 2011 in a block design (see Fig. S1 in Supplementary material) on a previously unman- 
aged grassland ( $51.560 \mathrm{~N}, 9.956 \mathrm{E})$ in Göttingen, Germany. Cuttings were planted by inserting the whole length of the cutting into the soil $(1 \mathrm{~cm}$ underneath the ground surface) with $0.75 \times 0.75 \mathrm{~m}$ spacing. The plantation was watered just after planting and in August of 2011. Weed control was done by cutting weeds at the end of August in 2011. A soil survey was carried out by drilling a Pürckhauer soil driller (Eijkelkamp, Giesbeek, Netherlands) in a regular grid of $5 \times 5 \mathrm{~m}$ into the soil and classifying each soil parameter at each point according to the German soil classification system (Ad-Hoc-Arbeitsgruppe 2005). Especially, the height of the $\mathrm{Cv}$-horizon, i.e., the transition zone between the soil solum and the weathered rock with high content of coarse rock fragments was addressed. Soil depth data were digitized and interpolated in a GIS-system (Arc-Info ${ }^{\oplus}$ version 5.01, Environmental Systems Research Institute, Redlands, California - Fig. 1). The N concentrations in the upper layer $(0-60 \mathrm{~cm})$ of the deep and shallow soils were similar $(0.15 \pm$ $0.04 \% \mathrm{~g} \mathrm{~N} \mathrm{~g}^{-1}$ dry soil).

During the years 2011 to 2014, the mean temperature was $14.9 \pm 0.3^{\circ} \mathrm{C}$ in Göttingen, total precipitation was $295.6 \pm 35.6 \mathrm{~mm}$ and sunshine duration was $968 \pm 61.40 \mathrm{~h}$ in the growth period from April to August (Wetterstation Goettingen 2014). The precipitation in spring (April to Mai) during the time of bud break and the start of the main growth phase were $69 \mathrm{~mm}$ in 2012, $160 \mathrm{~mm}$ in 2013, and $109 \mathrm{~mm}$ in 2014.

\section{Growth and biomass determination}

The heights and basal diameters of the shoots were measured at end of the growing season in the year of 2011 and 2012 and before the growing season in 2014 using a meter stick and a digital caliper, respectively.

Seven plants of each species in the deep and shallow soil of the plantation (Fig. 1) were randomly selected for each harvest. Harvests were carried out when the terminal buds of main shoots of poplars had been formed in the years 2012, 2013 and 2014. At harvest, fresh biomass of plant tis- sues (roots, stems and leaves) was measured. Stems, leaves and roots were ovendried at $60^{\circ} \mathrm{C}$ for 3 weeks and weighed to determine dry biomass.

\section{Leaf area determination}

Three young and three old leaves were selected for each plant at each harvest to determine the leaf area. The leaves were weighed and scanned together with a ruler, and used to determine the leaf area with the image analysis software Image $J^{\circledR}$ (NIH, Bethesda, Maryland, USA). The total leaf area was calculated as: total leaf area $=$ leaf area of 6 selected leaves $x$ fresh weight of total leaves / fresh weight of 6 selected leaves. Specific leaf area (SLA) was calculated as: leaf area / leaf dry mass $\left(\mathrm{m}^{2} \mathrm{~g}^{-1}\right)$.

\section{Nitrogen analysis}

The leaves used for leaf area determination were pooled and milled. The whole stem $(2012,2013)$ was cut into small pieces and milled. Stem segments from the bottom of the main stem were milled for plants in 2014. One root including fine roots from each plant was milled. The plant tissues and soil samples were milled to fine powders ( $M M 2$ Retsch, Hannover, Germany). About $1 \mathrm{mg}$ (0.7-0.9 mg) of the milled samples were weighed (Sartorius Supermicro S4 ${ }^{\circledR}$, Göttingen, Germany) into tin capsules (Hekatech, Wegberg, Germany). Nitrogen concentrations of the samples were determined using the Elemental Analyzer EA1108 ${ }^{\circledR}$ (Carlo Erba Strumentazione, Rodano, Italy). Acetanilide (10.36\% N - Carlo Erba Strumentazione) was used as the standard.

\section{Nitrogen uptake and nitrogen use efficiency}

Because leaves are shed in autumn, the annual $\mathrm{N}$ uptake rate was calculated without considering the $\mathrm{N}$ content in leaves from the previous year (eqn. 1):

$$
\begin{aligned}
N_{\text {gain }}\left(g y^{-1}\right)= & N_{\text {leaf }}+\text { stem }+ \\
& \text { root }{ }_{\text {current year }}-N \text { stem }+ \\
& \text { root } \text { previous year }^{-}
\end{aligned}
$$

Nitrogen use efficiency (NUE) has been defined as the amount of biomass produced per unit of $\mathrm{N}$ taken up from the soil. The amount of stem biomass produced per unit of $\mathrm{N}$ taken up from the soil is of interest for the calculation of wood nitrogen use efficiency (WNUE).

To determine the annual changes of nitrogen use efficiency for wood biomass production, wood nitrogen use efficiency was calculated as (eqn. 2):

$$
W N U E=\frac{\text { Stem biomass } \text { gain }\left(g y^{-1}\right)}{N \text { gain }\left(g y^{-1}\right)}
$$

To determine the annual changes of nitrogen use efficiency for the whole plant biomass production, NUE was calculated as (eqn. 3):

$$
N U E=\frac{\text { Biomass } \operatorname{gain}\left(g y^{-1}\right)}{N \operatorname{gain}\left(g y^{-1}\right)}
$$

with (eqn. 4):

$$
\begin{aligned}
& \text { Biomass gain }(\mathrm{g})= \\
& \text { Biomass }_{\text {current year }}(\text { leaf }+ \text { stem }+ \text { root })- \\
& \text { Biomass }_{\text {previous year }}(\text { stem }+ \text { root })
\end{aligned}
$$

and (eqn. 5):

$$
\begin{aligned}
& \text { Stem biomass gain }(g)= \\
& \text { Biomass }_{\text {current year }}(\text { stem })- \\
& \text { Biomass }_{\text {previous year }}(\text { stem })
\end{aligned}
$$

\section{Statistical analyses}

Data are means \pm SE of 5 or 7 individual plants. To determine differences between treatments, the Student's t-test $(\alpha=0.05)$ was used. To determine poplar species and soil depth effects, two-way ANOVA was performed and the differences between means were tested using the post-hoc Tukey's HSD test. All analyses were carried out using the software package Origin $\mathrm{Pro}^{\oplus}$ ver. 8 (OriginLab Corporation, Northampton, USA).

\section{Results}

\section{Survival, growth and biomass} production

The soil depths were $70-100 \mathrm{~cm}$ for the deep and $20-50 \mathrm{~cm}$ for the shallow soil con-

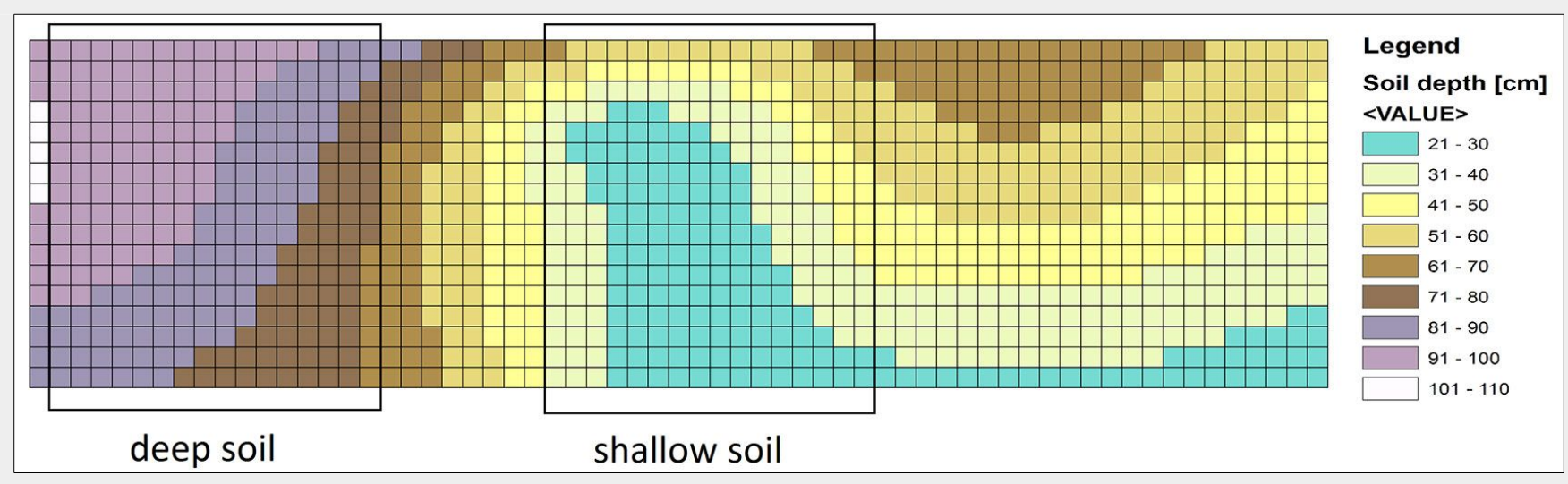

Fig. 1 - Map of soil depth in the poplar plantation, determined according to the Ad-Hoc-Arbeitsgruppe (2005), and digitized and interpolated in an ARC/INFO GIS system. 
Fig. 2 - Survival of Max1 and $\mathrm{H} 275$ in the deep soil (-d) and shallow soil (-s). Survival (\%) was calculated as: number of existing plants / total planted plants $\times 100$ (\%), $\mathrm{n}=160$.

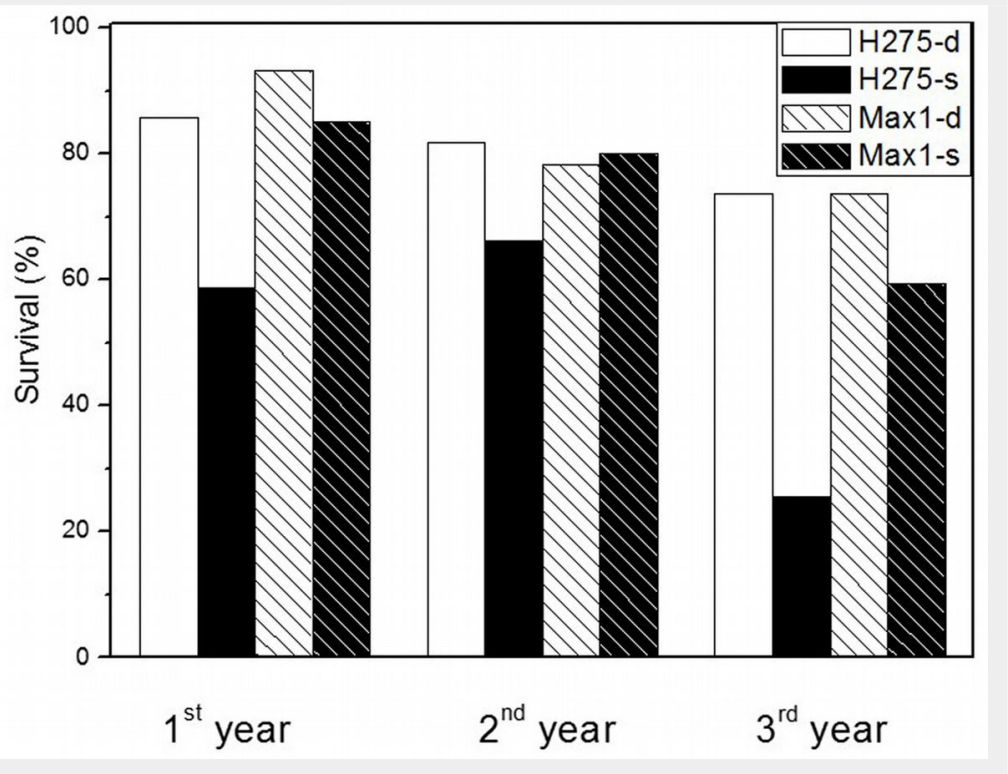

ditions, respectively (Fig. 1). Lower survival survival (about 74\%) was found in the deep with deep soil (Fig. 3A, Fig. 3B, Fig. 3C). of $\mathrm{H} 275$ and Max1 was found in the planta- soil for both poplar clones, whereas the tion on shallow soil than that on deep soil survival of $\mathrm{H} 275(26 \%)$ was lower than that (Fig. 2). H275 showed a lower survival rate than Max1 in all three years on shallow soil (Fig. 2). After 3 years of planting, the same of Max1 (60\%) in the shallow soil (Fig. 2).

$\mathrm{H} 275$ and Max1 showed significant growth decline on shallow soil compared
Height and diameter growth of Max1 was similar to that of $\mathrm{H}_{275}$ in first two years (Fig. 3A, Fig. 3B). There were no significant differences in height and diameter of $\mathrm{H} 275$ and Max1 on deep soil in year 3. However,
Fig. 3 - Height, root collar diameter, total leaf area and specific leaf area of Max1 and $\mathrm{H} 275$ on the deep soil (-d) and shallow soil $(-\mathrm{s})$. Data $(n=7)$ are mean \pm SE. Different letters above the bars indicate significant differences after Student's t-test $(p<0.05)$.
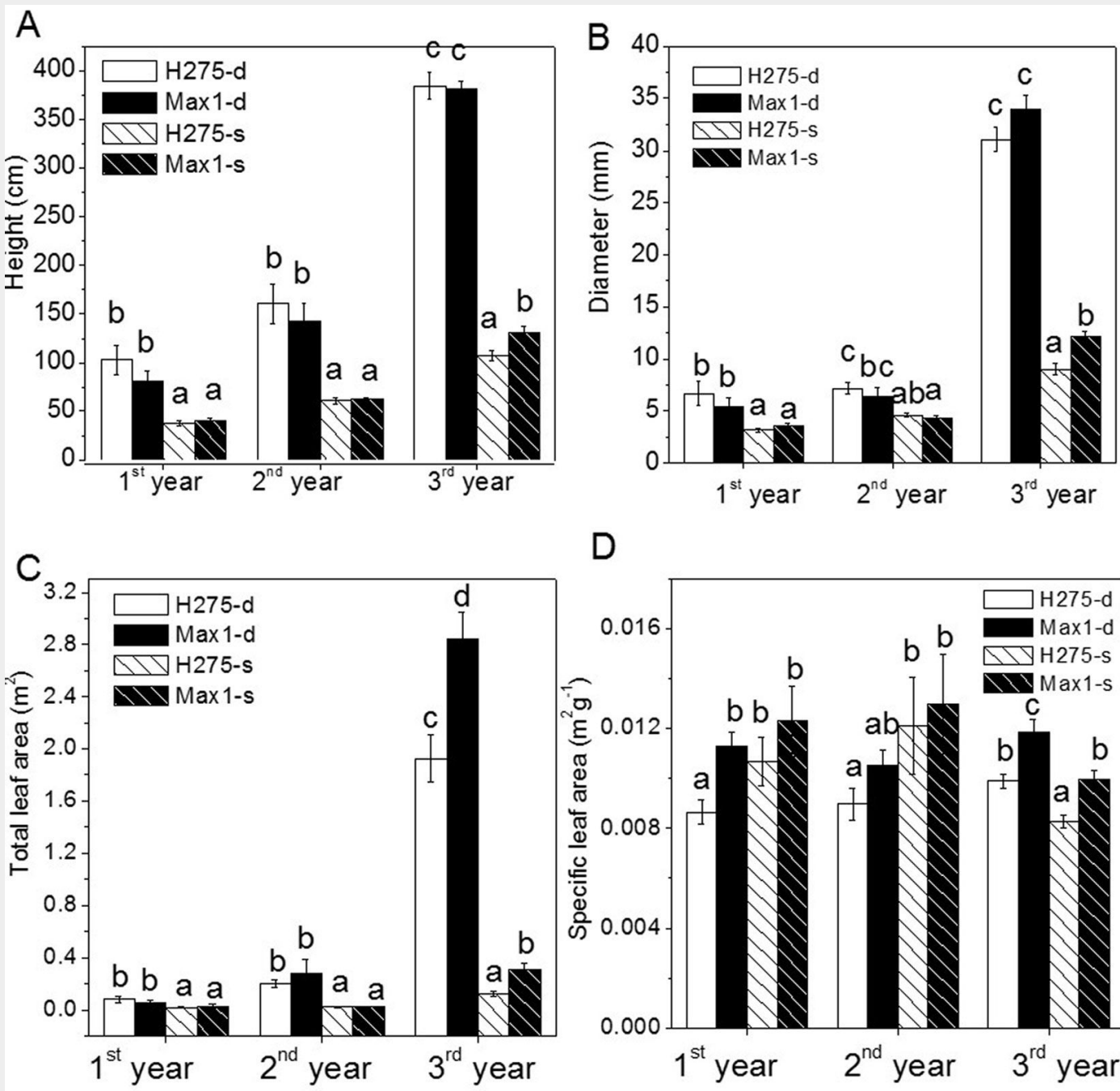

D

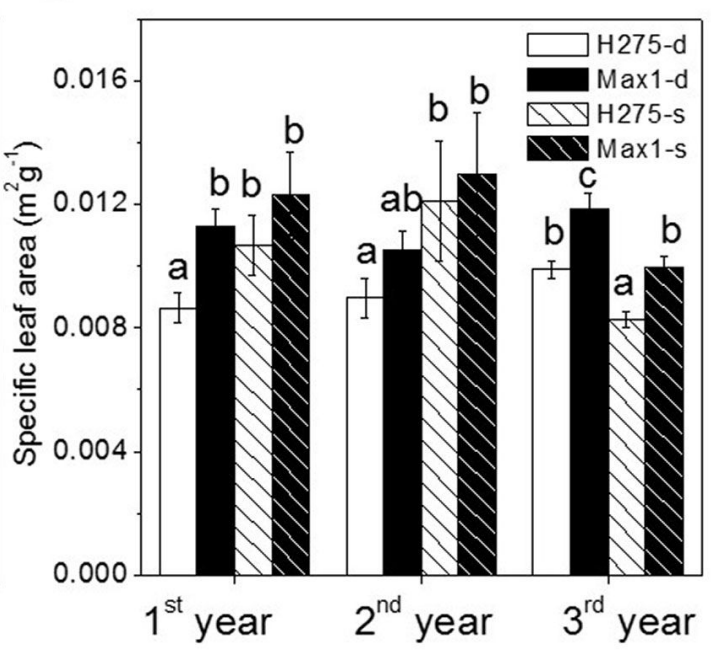



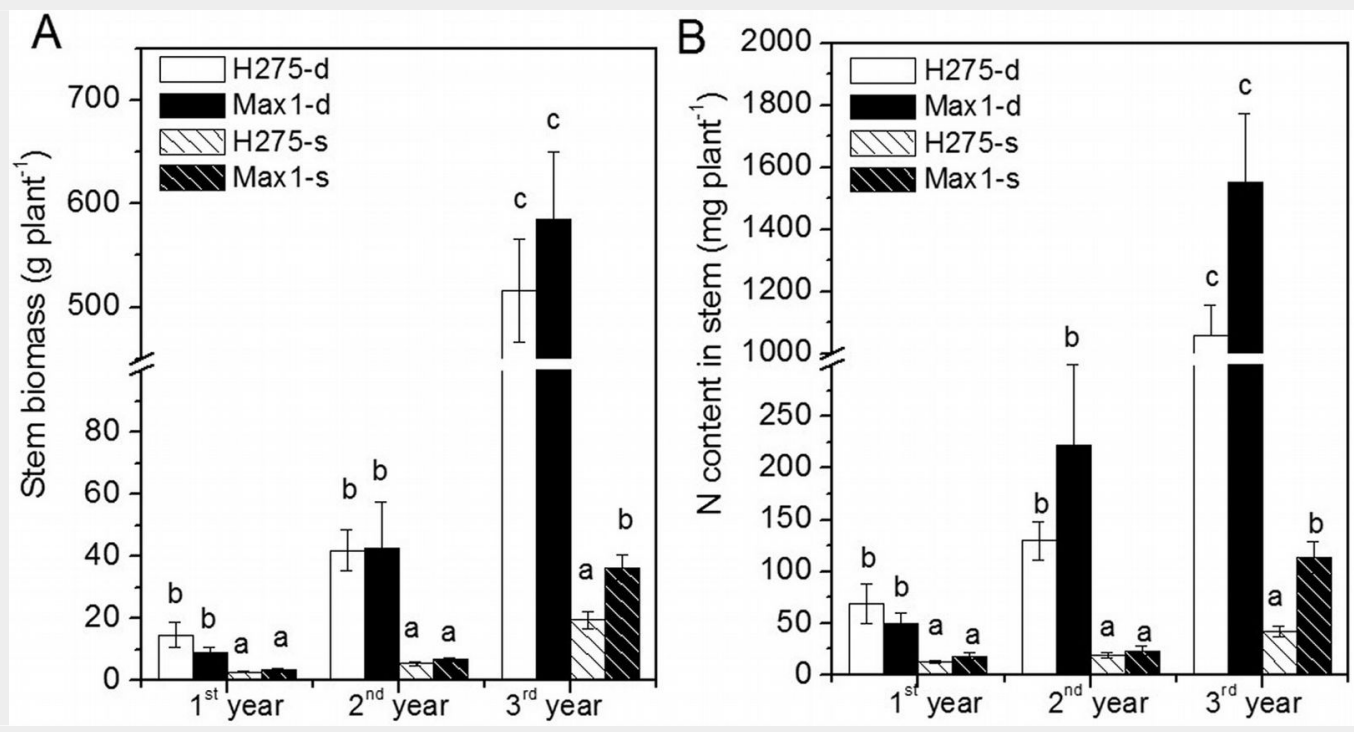

Fig. 4 - Stem biomass and stem nitrogen content of Max1 and $\mathrm{H} 275$ on deep soil (-d) and shallow soil $(-s)$. Data are means \pm SE $(\mathrm{n}=5)$. Different letters above the bars indicate significant differences between the means after Student's t-test $(p<0.05)$.

Tab. 1 - Biomass and shoot:root ratio (g year-1) of Max1 and H275 on deep soil (-d) and shallow soil (-s). (Root:shoot ratio): biomass of roots / biomass of stems and leaves. Data are means $\pm S E(n=7)$. Different letters in columns indicate significant differences after Student's $t$-test $(p<0.05)$. P-values of the two-way ANOVA with factor species $\left(P_{\text {species }}\right)$, soil depth $\left(P_{\text {soil }}\right)$ and the interactions of species and soil depth $\left(P_{\text {species } \times \text { soil }}\right)$ are given.

\begin{tabular}{|c|c|c|c|c|}
\hline Parameter & Clone / Effect & $1^{\text {st }}$ year & $2^{\text {nd }}$ year & $3^{\text {rd }}$ year \\
\hline \multirow{7}{*}{ Biomass - whole plant } & H275-d & $25.58 \pm 7.28^{b}$ & $66.69 \pm 9.83^{b}$ & $750.12 \pm 68.50^{c}$ \\
\hline & Max1-d & $14.95 \pm 3.33^{b}$ & $72.53 \pm 26.39^{b}$ & $882.53 \pm 90.83^{c}$ \\
\hline & H275-s & $4.97 \pm 0.44^{\mathrm{a}}$ & $7.64 \pm 0.80^{\mathrm{a}}$ & $36.52 \pm 4.80^{\mathrm{a}}$ \\
\hline & Max1-s & $5.88 \pm 1.04^{a}$ & $9.08 \pm 0.72^{a}$ & $73.76 \pm 9.36^{b}$ \\
\hline & $P_{\text {species }}$ & 0.25 & 0.83 & 0.23 \\
\hline & $\mathrm{P}_{\text {soil }}$ & $<0.01$ & $<0.01$ & $<0.01$ \\
\hline & $P_{\text {species } \times \text { soil }}$ & 0.17 & 0.90 & 0.49 \\
\hline \multirow{7}{*}{ Root:shoot ratio } & H275-d & $0.06 \pm 0.01^{a}$ & $0.06 \pm 0.01^{\mathrm{a}}$ & $0.06 \pm 0.01^{\mathrm{a}}$ \\
\hline & Max1-d & $0.08 \pm 0.01^{\mathrm{b}}$ & $0.09 \pm 0.00^{\mathrm{b}}$ & $0.07 \pm 0.00^{\mathrm{ab}}$ \\
\hline & $\mathrm{H} 275-\mathrm{s}$ & $0.12 \pm 0.02^{b}$ & $0.14 \pm 0.02^{c}$ & $0.07 \pm 0.01^{b c}$ \\
\hline & Max1-s & $0.08 \pm 0.02^{\mathrm{ab}}$ & $0.16 \pm 0.01^{c}$ & $0.10 \pm 0.01^{c}$ \\
\hline & $P_{\text {species }}$ & 0.72 & 0.04 & 0.19 \\
\hline & $\mathrm{P}_{\text {soil }}$ & 0.21 & $<0.01$ & 0.03 \\
\hline & $P_{\text {species } \times \text { soil }}$ & 0.07 & 0.19 & 0.73 \\
\hline
\end{tabular}

Tab. 2 - Nitrogen concentration in stems, leaves and roots of Max1 and H275 on deep soil (-d) and shallow soil (-s). (*): N stem \% in the basal stem is shown for the $3^{\text {rd }}$ year. Data $(n=5)$ are means \pm SE $\left(g\right.$ year $\left.{ }^{-1}\right)$. Different letters in columns indicate significant differences after Student's t-test $(p<0.05)$. P-values of two-way ANOVA test with factor species $\left(P_{\text {species }}\right)$, soil depth $\left(P_{\text {soil }}\right)$ and the interactions of species and soil depth $\left(P_{\text {species } \times \text { soii }}\right)$ are given.

\begin{tabular}{|c|c|c|c|c|}
\hline Parameter & Clone / Effect & $1^{\text {st }}$ year & $2^{\text {nd }}$ year & $3^{\text {rd }}$ year \\
\hline \multirow{7}{*}{$\mathrm{N}$ leaf \% } & H275-d & $1.29 \pm 0.12^{b}$ & $1.07 \pm 0.02^{\mathrm{a}}$ & $1.71 \pm 0.07^{c}$ \\
\hline & Max1-d & $1.45 \pm 0.07^{b c}$ & $1.35 \pm 0.08^{b}$ & $1.78 \pm 0.06^{c}$ \\
\hline & H275-s & $0.96 \pm 0.08^{a}$ & $1.01 \pm 0.04^{\mathrm{a}}$ & $1.11 \pm 0.05^{\mathrm{a}}$ \\
\hline & Max1-s & $1.17 \pm 0.10^{a}$ & $1.04 \pm 0.02^{\mathrm{a}}$ & $1.48 \pm 0.04^{b}$ \\
\hline & $P_{\text {species }}$ & 0.06 & 0.01 & $<0.01$ \\
\hline & $P_{\text {soil }}$ & $<0.01$ & $<0.01$ & $<0.01$ \\
\hline & $P_{\text {species } \times \text { soil }}$ & 0.82 & 0.04 & 0.11 \\
\hline \multirow{7}{*}{ N stem \%* } & $H 275-d$ & $0.46 \pm 0.02^{\mathrm{a}}$ & $0.32 \pm 0.03^{a}$ & $0.21 \pm 0.01^{\mathrm{a}}$ \\
\hline & Max1-d & $0.60 \pm 0.04^{\mathrm{b}}$ & $0.54 \pm 0.03^{b}$ & $0.26 \pm 0.01^{\mathrm{b}}$ \\
\hline & H275-s & $0.48 \pm 0.04^{\mathrm{a}}$ & $0.34 \pm 0.01^{\mathrm{a}}$ & $0.22 \pm 0.02^{\mathrm{ab}}$ \\
\hline & Max1-s & $0.56 \pm 0.03^{b}$ & $0.34 \pm 0.04^{\mathrm{a}}$ & $0.31 \pm 0.02^{c}$ \\
\hline & $P_{\text {species }}$ & $<0.01$ & $<0.01$ & $<0.01$ \\
\hline & $P_{\text {soil }}$ & 0.74 & 0.02 & $<0.01$ \\
\hline & $P_{\text {species } \times \text { soil }}$ & 0.41 & $<0.01$ & 0.02 \\
\hline \multirow{7}{*}{$\mathrm{N}$ root $\%$} & $\mathrm{H} 275-\mathrm{d}$ & $0.35 \pm 0.01^{\mathrm{a}}$ & $0.37 \pm 0.04^{\mathrm{ab}}$ & $0.28 \pm 0.02^{\mathrm{a}}$ \\
\hline & Max1-d & $0.42 \pm 0.02^{b}$ & $0.36 \pm 0.02^{b}$ & $0.24 \pm 0.03^{\mathrm{a}}$ \\
\hline & H275-s & $0.42 \pm 0.03^{b}$ & $0.29 \pm 0.02^{\mathrm{a}}$ & $0.20 \pm 0.04^{\mathrm{a}}$ \\
\hline & Max1-s & $0.47 \pm 0.07^{b}$ & $0.35 \pm 0.03^{\mathrm{ab}}$ & $0.25 \pm 0.03^{a}$ \\
\hline & $P_{\text {species }}$ & 0.16 & 0.5 & 0.72 \\
\hline & $P_{\text {soil }}$ & 0.14 & 0.19 & 0.43 \\
\hline & $P_{\text {species } \times \text { soil }}$ & 0.77 & 0.37 & 0.35 \\
\hline
\end{tabular}


Tab. 3 - Nitrogen uptake rate $\left(g\right.$ year $\left.{ }^{-1}\right)$ of Max1 and H275 on deep soil (-d) and shallow soil (-s). Data are means $\pm S E$ ( $\left.n=5\right)$. Different letters in columns indicate significant differences after Student's t-test $(p<0.05)$. P-values of the two-way ANOVA carried out with factor species $\left(P_{\text {species }}\right)$, soil depth $\left(P_{\text {soil }}\right)$ and the interactions of species and soil depth $\left(P_{\text {species } \times \text { soil }}\right)$ are given.

\begin{tabular}{lccccccc}
\hline Year & H275-d & Max1-d & H275-s & Max1-s & $\boldsymbol{P}_{\text {species }}$ & $\boldsymbol{P}_{\text {soil }}$ & $\boldsymbol{P}_{\text {species } \times \text { soil }}$ \\
\hline $2^{\text {nd }}$ year & $0.31 \pm 0.06^{\mathrm{b}}$ & $0.49 \pm 0.22^{\mathrm{b}}$ & $0.02 \pm 0.00^{\mathrm{a}}$ & $0.03 \pm 0.01^{\mathrm{a}}$ & 0.42 & $<0.01$ & 0.44 \\
$3^{\text {rd }}$ year & $4.34 \pm 0.46^{\mathrm{c}}$ & $5.74 \pm 0.67^{\mathrm{d}}$ & $0.19 \pm 0.03^{\mathrm{a}}$ & $0.56 \pm 0.10^{\mathrm{b}}$ & 0.04 & $<0.01$ & 0.22 \\
\hline
\end{tabular}

Fig. 5 - Annual nitrogen use efficiency in stem and whole plant of Max1 and $\mathrm{H} 275$ on deep soil (-d) and shallow soil $(-s)$. Data $(n=5)$ are means $\pm \mathrm{SE}$. Different letters above the bars indicate significant differences after Student's t-test $(p<0.05)$.

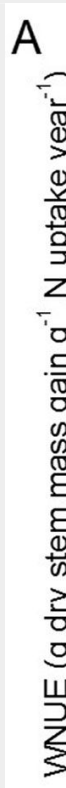

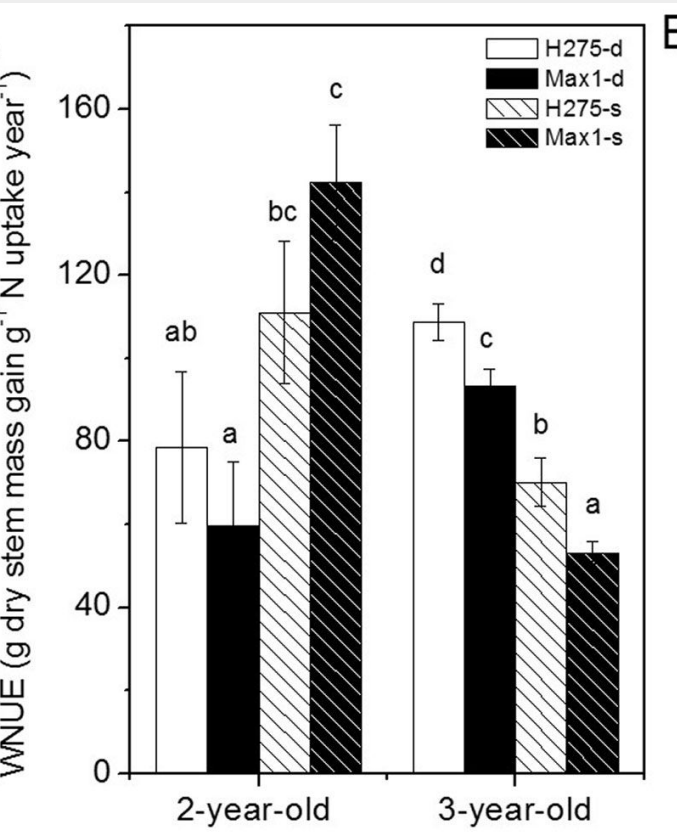

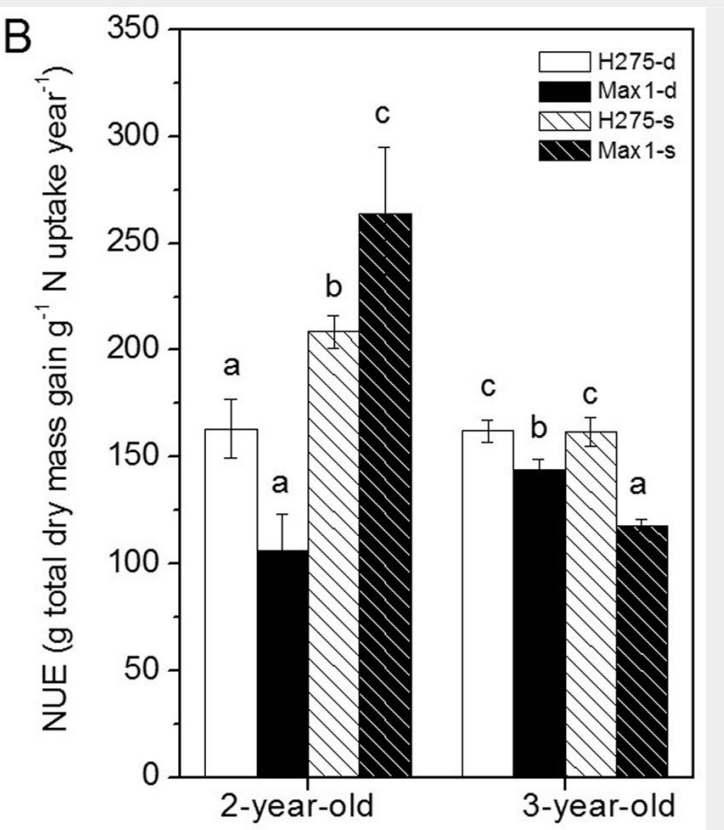

the leaf area of Max1 was higher than that of $\mathrm{H} 275$ (Fig. 3C). Max1 was significantly taller and thicker in stem on shallow soil as compared with $\mathrm{H} 275$ (Fig. 3A, Fig. 3B) in the third year.

SLA of three-year-old poplar Max1 and H275 was significantly lower for plants on shallow soil than for plants on deep soil ( $p$ $<0.01$ - Fig. 3D). SLA of $\mathrm{H} 275$ was significantly lower than that of Max1 after 3 years of growth (Fig. 3D).

Soil depth was the main factor influencing biomass production of both clones in each year ( $p<0.01$ - Fig. 4A, Tab. 1). H275 and Max1 produced significant lower stem and total biomass on shallow soil compared with deep soil (Fig. 4A, Tab. 1). Initially, stem and total biomass production of $\mathrm{H} 275$ and Max1 were not significantly different on the same soil conditions. In the third year, Max1 produced significantly more stem and total biomass than $\mathrm{H} 275$ on shallow soil (Fig. 4A, Tab. 1). H275 and Max1 had significant higher root:shoot ratio on shallow soil compared with deep soil in second year and third year. $\mathrm{H} 275$ had lower root:shoot ratio than Max1 on deep soil; root:shoot ratio was significantly different between $\mathrm{H} 275$ and Max1 in the second year (Tab. 1).

\section{$N$ concentration, $N$ uptake and $N$ use efficiency}

Poplars on deep soil exhibited significantly higher leaf $\mathrm{N}$ concentrations than those of on shallow soil (Tab. 2). Leaf and stem $\mathrm{N}$
concentrations of Max1 were significantly higher than those of $\mathrm{H} 275$ (Tab. 2). There were no significant differences in $\mathrm{N}$ concentrations of roots between Max 1 and H275 (Tab. 2). N contents of poplar stems were lower on shallow soil compared with those on deep soil (Fig. 4B). There were no significant differences between stem $\mathrm{N}$ contents of $\mathrm{H} 275$ and Max1 on the same soil conditions in the first two years. In the third year, stem $\mathrm{N}$ content of Max1 was higher than that of $\mathrm{H} 275$ on shallow soil (Fig. 4B).

Poplars on deep soil had significantly higher $\mathrm{N}$ uptake rate than those of on shallow soil (Tab. 3). There were no differences between clones for $\mathrm{N}$ uptake in the $2^{\text {nd }}$ year, but Max1 had significantly higher $\mathrm{N}$ uptake rate than $\mathrm{H} 275$ in the $3^{\text {rd }}$ year (Tab. 3).

$\mathrm{N}$ use efficiency for wood biomass production (WNUE) and for whole plant biomass production (NUE) was lower in $\mathrm{H}_{2} 75$ and Max1 on the deep soil than in poplars on shallow soil in the $2^{\text {nd }}$ year (Fig. $5 \mathrm{~A}$ and $5 \mathrm{~B}$ ). However, in the $3^{\text {rd }}$ year, WNUE of both poplar clones on deep soil was higher than on shallow soil (Fig. 5B); NUE was similar for $\mathrm{H} 275$ on deep and shallow soil but Max1 had lower NUE on shallow soil than on deep soil (Fig. 5B). No clone differences were found for WNUE and NUE in the second year, but lower nitrogen use efficiency for wood and total biomass production of
Max 1 than those of $\mathrm{H} 275$ in the third year.

\section{Discussion}

\section{Shallow soil restricts poplar productivity}

Root production is an important process driving the acquisition of soil resources and affecting the adaptation of plants to suboptimal soil conditions (Lynch 1995, Reich 2002). Shallow soils, often occurring in marginal lands, restrict the rooting depth of trees (Crow 2005). In this study, we demonstrated that poplar biomass was remarkably decreased on shallow soil (3- to 6 -fold initially and more than 10-fold in the $3^{\text {rd }}$ growth year), indicating that shallow soil drastically hindered both root and shoot formation in poplar plantations. The insufficient moisture storage capacity that usually characterizes shallow soils makes drought stress one of the main threats for poplar plantations (Isebrands \& Richardson 2014). Indeed, we observed an increase in specific leaf area for poplar clones growing on shallow soil, which may represent an adaptation to drought stress, as thicker leaves may have lower transpiration rates (Liu \& Stützel 2004, Hennig et al. 2015). Moreover, the root:shoot biomass ratio was higher in plants grown on shallow soils, suggesting that they were affected by water shortage (Tab. 1, Fig. 3). It was notable that in, contrast to the aforementioned relationships, the specific leaf area 
of poplars on shallow soil was decreased in the $3^{\text {rd }}$ growth year. A possible explanation for this unexpected finding is that trees may regulate water and nutrient balance at the whole-plant level. In the $3^{\text {rd }}$ year, the leaf area of poplars on deep soil was massively increased, while the trees on shallow soil produced only small increments in leaf area compared to the preceding growth phases. Under these conditions, poplars with large total leaf area may also have to cope with water limitations.

In this study, both poplar clones exhibited a decreased survival in the shallow soil area of the plantation. The shallow soil effect was strongest in the third growth year, resulting in the increased mortality of both clones (Fig. 2). The survival of $\mathrm{H} 275$ on shallow soil was much lower than that of Max1, especially in the $3^{\text {rd }}$ year after planting (Fig. 2). The difference in stress resistance of hybrid poplars Max1 and $\mathrm{H} 275$ may be explained by different origins of their parents, P. maximowiczii, P. trichocarpa and $P$. nigra. In fact, $P$. maximowiczii, which is a common parent of both hybrids, is naturally distributed along the Pacific coast of eastern Asia (China, Korea, and Japan - Isebrands \& Richardson 2014). P. trichocarpa is natively found along rivers and streams of western North America, and may be sensitive to water limitation (Street et al. 2006, Bogeat-Triboulot et al. 2007, Isebrands \& Richardson 2014). P. nigra is native to Europe and can be found in riparian habitats as well as in arid regions (Thieret 1982, Khamzina et al. 2006). P. nigra shows a wide range of adaptive mechanisms in response to drought, which is probably caused by its genomic plasticity (Viger \& Taylor 2012). Poplar hybrids with $P$. nigra as parent have proven to be more resistant to drought than those having $P$. trichocarpa as parent (Tschaplinski et al. 1998). Accordingly, we found that Max1 ( $P$. nigra $\times P$. maximowiczii) was more tolerant to shallow soil stress than $\mathrm{H} 275$, which originated from crossing $P$. trichocarpa and P. maximowiczii. It is likely that an important factor contributing to the improved performance of Max1 under shallow soil stress was a higher drought adaptability of this clone as compared with $\mathrm{H} 275$.

\section{Decreases in wood nitrogen use efficiency as an adaptation to soil constraints}

Max1 showed significantly higher $\mathrm{N}$ uptake rate than $\mathrm{H} 275$ in the $3^{\text {rd }}$ year (Tab. 3 ). It has been reported that the rate of $\mathrm{N}$ uptake of poplars can vary during plant development as well as between poplar species and sites (McLaughlin et al. 1987, Pregitzer et al. 1990, Miller \& Hawkins 2003). N uptake of poplars is adjusted by molecular regulation of nitrate transporters and by $\mathrm{N}$ metabolism in response to different environmental conditions (Ehlting et al. 2007, Li et al. 2012, Bai et al. 2013). Furthermore, several studies reported that droughtstress related genes are significantly regu- lated at the transcription level by $\mathrm{N}$ fertilization or starvation (Euring et al. 2014, Luo et al. 2015), suggesting that the $\mathrm{N}$ metabolism is linked with stress tolerance. This is supported by the finding that poplars overexpressing glutamine synthetase showed higher $\mathrm{N}$ uptake rates and higher drought tolerance than wild-type plants (Molina-Rueda \& Kirby 2015). Therefore, the higher $N$ uptake and $\mathrm{N}$ concentrations in leaf and stem tissues of the clone Max1 found in this study (Tab. 2) may also have contributed to its better adaptation to shallow soil compared to $\mathrm{H} 275$.

In general, nutrient use efficiency in plants decrease with increasing soil fertility (Vitousek et al. 1995, Broeckx et al. 2014). Our results of the second year agree with this finding, when a higher WNUE was observed for poplar clones grown on shallow soil, but not with the results of the third year of this study. Indeed, there seemed to be a trade-off between biomass production and environmental stress adaptation for nitrogen utilization in the third year. Clone Max1 decreased its nitrogen usage for wood (WNUE) and whole plant biomass production (NUE) on shallow soil, while $\mathrm{H} 275$ decreased only WNUE on shallow soil. These findings indicate that the acquisition of $\mathrm{N}$ was relatively higher than biomass production in Max1, which may have contributed to its better performances under shallow soil stress compared with $\mathrm{H} 275$.

A trade-off between NUE and water use efficiency (WUE) within species has been demonstrated in many studies (Field et al. 1983, Lajtha \& Whitford 1989, Patterson et al. 1997, Sadras \& Rodriguez 2010, Broeckx et al. 2014). For example, Broeckx et al. (2014) showed that a trade-off between intrinsic water use efficiency and photosynthetic $\mathrm{N}$ use efficiency existed among six poplar genotypes, but only when soil water availability was restricted. Considering that drought stress was likely an important limiting factor on shallow soil, the variation in WNUE or NUE might be related to differences in water availability among different years. Overall, Max1 exhibited higher growth and lower NUE and WNUE than $\mathrm{H} 275$ in the third year, when the mortality of $\mathrm{H} 275$ was high. Our results suggest that the high capacity of $\mathrm{N}$ acquisition was combined with higher stress tolerance in the clone Max1, thereby this genotype is more suitable for growth on marginal land. However, the total biomass yield of both clones was low at the study site compared with the expected mean yield of 10 tons ha $a^{-1} y^{-1}$ (Liesebach et al. 1999). Therefore, genotypes that can produce reasonable yields under the study conditions still have to be identified. Nonetheless, it should be noted that these genotypes have substantial beneficial economic and ecological effects on arable soil, as they also contribute to prevent $\mathrm{N}$ leaching (Bredemeier et al. 2015).

\section{Conclusions}

In conclusion, we demonstrated that soil depth was an important factor limiting the growth, biomass production and survival of the studied poplar clones. Max1 and H275 showed different adaptation to soil depth constraints, the former showing higher survival and nitrogen concentrations than the latter. Enhanced $\mathrm{N}$ uptake may positively affect water usage during dry season. In the context of global change, understanding the mechanism of adaptation to environmental changes is needed to design more efficient and watersaving poplar cropping systems. This study contributes to better understanding the consequences of a changing environment on poplar growth and species adaptation. The comparison between the performance of clones $\mathrm{H} 275$ and Max1 suggest that the decrease in nitrogen use efficiency is a necessary trade-off to adapt to a stressful environment.

With regard to plantation management, our results show that not only low productivity but also high mortality may impinge on the yield of poplar plantations on marginal land. We demonstrated that the clone H275 was unsuitable for these conditions. Based on our results, testing a wider range of clones with high drought tolerance and an improved ability to form root biomass for their performance on shallow soils is advised. Biotechnological approaches such as protoplast fusion lines may also be a valid alternative to conventional breeding or genetic engineering for achieving more stress tolerant poplar genotypes (Hennig et al. 2015).

\section{Acknowledgements}

Author's contribution: DE carried out the field measurements, sampling and writing the manuscript; AP conceived the study and helped to draft the manuscript; MJ carried out soil depth characterization; CG, JT and SA performed field measurements and sampling.

We are grateful to B. Faust for helping with growth measurements and sample preparation and to $\mathrm{G}$. Langer-Kettner for $\mathrm{N}$ analyses. We acknowledge financial support by the BMBF via the program "BEST Bioenergie-Regionen stärken”. JT acknowledges financial support by a postdoctoral fellowship awarded by the China Scholarship Council (CSC).

\section{References}

Ad-Hoc-Arbeitsgruppe (2005). Bodenkundliche Kartieranleitung [Soil Mapping] $\left(5^{\text {th }}\right.$ edn). Bundesanstalt für Geowissenschaften und Rohstoffe, Stuttgart, Germany, pp. 127. [in German] Bai H, Euring D, Volmer K, Janz D, Polle A (2013). The nitrate transporter (NRT) gene family in poplar. PloS ONE 8: e72126. - doi: 10.1371/jour nal.pone.0072126

Bogeat-Triboulot $M$, Brosché $M$, Renaut J, Jouve L, Le Thiec D, Fayyaz P, Vinocur B, Witters E, Laukens K, Teichmann T (2007). Gradual soil water depletion results in reversible changes of 
gene expression, protein profiles, ecophysiology, and growth performance in Populus euphratica, a poplar growing in arid regions. Plant physiology 143: 876-892. - doi: 10.1104/pp.106. 088708

Bredemeier M, Busch G, Hartmann L, Jansen M, Richter F, Lamersdorf N (2015). Fast growing plantations for wood production-integration of ecological effects and economic perspectives. Frontiers in Bioengineering and Biotechnology 3: 1-14. - doi: 10.3389/fbioe.2015.00072

Broeckx LS, Fichot R, Verlinden MS, Ceulemans R (2014). Seasonal variations in photosynthesis, intrinsic water-use efficiency and stable isotope composition of poplar leaves in a short-rotation plantation. Tree Physiology 34 (7): 701-715. - doi: 10.1093/treephys/tpu057

Bungart R, Hüttl RF (2004). Growth dynamics and biomass accumulation of 8-year-old hybrid poplar clones in a short-rotation plantation on a clayey-sandy mining substrate with respect to plant nutrition and water budget. European Journal of Forest Research 123: 105-115. - doi: 10.1007/s10342-004-0024-8

Burgess J, Szlavecz K, Rajakaruna N, Swan C (2015). Ecotypic differentiation of mid-Atlantic Quercus species in response to ultramafic soils. Australian Journal of Botany 63 (4): 308. - doi: 10.1071/BT14274

Castro-Rodríguez V, García-Gutiérrez A, Canales J, Cañas RA, Kirby EG, Avila C, Cánovas FM (2015). Poplar trees for phytoremediation of high levels of nitrate and applications in bioenergy. Plant Biotechnology Journal 14 (1): 299312. - doi: 10.1111/pbi.12384

Crow $\mathrm{P}$ (2005). The influence of soils and species on tree root depth. Information Note 78, Forestry Commission, Edinburgh, UK, pp. 4.

Ehlting B, Dluzniewska P, Dietrich $\mathrm{H}$, Selle A, Teuber M, Hänsch R, Nehls U, Polle A, Schnitzler J, Rennenberg H, Gessler A (2007). Interaction of nitrogen nutrition and salinity in Grey poplar (Populus tremula $\times$ alba). Plant, Cell and Environment 30: 796-811. - doi: 10.1111/j.1365-3040.20 07.01668.x

Euring D, Löfke C, Teichmann T, Polle A (2012). Nitrogen fertilization has differential effects on $\mathrm{N}$ allocation and lignin in two Populus species with contrasting ecology. Trees 26 (6): 19331942. - doi: 10.1007/s00468-012-0761-0

Euring D, Bai H, Janz D, Polle A (2014). Nitrogendriven stem elongation in poplar is linked with wood modification and gene clusters for stress, photosynthesis and cell wall formation. BMC Plant Biology 14: 391. - doi: 10.1186/s12870-0140391-3

Field C, Merino J, Mooney HA (1983). Compromises between water-use efficiency and nitrogen-use efficiency in five species of California evergreens. Oecologia 60 (3): 384-389. - doi: 10.1007/BFo0376856

Gan H, Jiao Y, Jia J, Wang X, Li H, Shi W, Peng C, Polle A, Luo Z (2015). Phosphorus and nitrogen physiology of two contrasting poplar genotypes when exposed to phosphorus and/or nitrogen starvation. Tree Physiology 36 (1): 2238. - doi: 10.1093/treephys/tpv093

Hennig A, Kleinschmit JRG, Schoneberg S, Löffler S, Janssen A, Polle A (2015). Water consumption and biomass production of protoplast fusion lines of poplar hybrids under drought stress. Frontiers in Plant Science 6: 242. - doi: $10.3389 /$ fpls.2015.00330

Isebrands JG, Richardson J (2014). Poplars and willows: trees for society and the environment. CABI, Canada, pp. 331-656. [online] URL: http:// books.google.com/books?id=36ANAwAAQBAJ Jiang D, Hao M, Fu J, Zhuang D, Huang Y (2014). Spatial-temporal variation of marginal land suitable for energy plants from 1990 to 2010 in China. Scientific Reports 4: 5816. - doi: 10.1038/ srepo5816

Kauter D, Lewandowski I, Claupein W (2003). Quantity and quality of harvestable biomass from Populus short rotation coppice for solid fuel use'a review of the physiological basis and management influences. Biomass and Bioenergy 24 (6): 411-427. - doi: 10.1016/So961-9534 (02)00177-0

Khamzina A, Lamers JP, Worbes M, Botman E, Vlek PL (2006). Assessing the potential of trees for afforestation of degraded landscapes in the Aral Sea Basin of Uzbekistan. Agroforestry Systems 66 (2): 129-141. - doi: 10.1007/s10457-0054677-1

Lajtha K, Whitford W (1989). The effect of water and nitrogen amendments on photosynthesis, leaf demography, and resource-use efficiency in Larrea tridentata, a desert evergreen shrub. Oecologia 80 (3): 341-348. - doi: 10.1007/BFo03 79035

Lee $\mathrm{K}$, Jose S (2003). Soil respiration, fine root production, and microbial biomass in cottonwood and loblolly pine plantations along a nitrogen fertilization gradient. Forest Ecology and Management 185 (3): 263-273. - doi: 10.1016/S0378-1127(03)00164-6

Li H, Li M, Luo J, Cao X, Qu L, Gai Y, Jiang X, Liu T, Bai H, Janz D (2012). N-fertilization has different effects on the growth, carbon and nitrogen physiology, and wood properties of slow-and fast-growing Populus species. Journal of Experimental Botany 63 (17): 6173-6185. - doi: 10.1093/ jxb/ers271

Liesebach M, Von Wuehlisch G, Muhs H (1999). Aspen for short-rotation coppice plantations on agricultural sites in Germany: effects of spacing and rotation time on growth and biomass production of aspen progenies. Forest Ecology and Management 121: 25-39. - doi: 10.1016/S0378-1127(98)00554-4

Liu F, Stützel H (2004). Biomass partitioning, specific leaf area, and water use efficiency of vegetable amaranth (Amaranthus spp.) in response to drought stress. Scientia horticulturae 102: 15-27. - doi: 10.1016/j.scienta.2003.11.014

Luo J, Li H, Liu T, Polle A, Peng C, Luo Z (2013). Nitrogen metabolism of two contrasting poplar species during acclimation to limiting nitrogen availability. Journal of Experimental Botany 64 (14): 4207-4224. - doi: 10.1093/jxb/ert234

Luo J, Zhou J, Li H, Shi W, Polle A, Lu M, Sun X, Luo Z (2015). Global poplar root and leaf transcriptomes reveal links between growth and stress responses under nitrogen starvation and excess. Tree Physiology 35: 1283-1302. - doi: 10.1093/treephys/tpvo91

Lynch J (1995). Root architecture and plant productivity. Plant Physiology 109: 7-13. [online] URL: http://www.ncbi.nlm.nih.gov/pmc/article s/PMC157559/pdf/1090007.pdf

McLaughlin RA, Hansen EA, Pope PE (1987).
Biomass and nitrogen dynamics in an irrigated hybrid poplar plantation. Forest Ecology and Management 18: 169-188. - doi: 10.1016/0378-11 27(87)90159-9

Millard P, Grelet G (2010). Nitrogen storage and remobilization by trees: ecophysiological relevance in a changing world. Tree Physiology 30: 1083-1095. - doi: 10.1093/treephys/tpq042 Miller BD, Hawkins BJ (2003). Nitrogen uptake and utilization by slow-and fast-growing families of interior spruce under contrasting fertility regimes. Canadian Journal of Forest Research 33: 959-966. - doi: 10.1139/x03-017

Molina-Rueda JJ, Kirby EG (2015). Transgenic poplar expressing the pine GS1a show alterations in nitrogen homeostasis during drought. Plant Physiology and Biochemistry 94: 181-190. doi: 10.1016/j.plaphy.2015.06.009

Nielsen UB, Madsen P, Hansen JK, Nord-Larsen T, Nielsen AT (2014). Production potential of 36 poplar clones grown at medium length rotation in Denmark. Biomass and Bioenergy 64: 99-109. - doi: 10.1016/j.biombioe.2014.03.030

Patterson TB, Guy RD, Dang QL (1997). Wholeplant nitrogen- and water-relations traits, and their associated trade-offs, in adjacent muskeg and upland boreal spruce species. Oecologia 110 (2): 160-168. - doi: 10.1007/s004420050145 Pleguezuelo C, Zuazo V, Bielders C, Bocanegra J, PereaTorres F, Martínez J (2015). Bioenergy farming using woody crops. A review. Agronomy for Sustainable Development 35 (1): 95119. - doi: 10.1007/s13593-014-0262-1

Polle A, Janz D, Teichmann T, Lipka V (2013). Poplar genetic engineering: promoting desirable wood characteristics and pest resistance. Applied Microbiology and Biotechnology 97 (13): 5669-5679. - doi: 10.1007/s00253-013-4940-8

Pregitzer KS, Dickmann DI, Hendrick R, Nguyen PV (1990). Whole-tree carbon and nitrogen partitioning in young hybrid poplars. Tree Physiology 7: 79-93. - doi: 10.1093/treephys/7.1-2-3-4.79 Reich PB (2002). Root-shoot relations: optimality in acclimation and adaptation or the "Emperors' New Clothes". In: "Plant Roots: the Hidden Half” (Waisel Y, Eshel A, Kafkaki U eds). Marcel Dekker, New York, USA, pp. 205-220. [online] URL: http://books.google.com/books?id=C7daC qhy1N8C

Rennenberg H, Wildhagen H, Ehlting B (2010). Nitrogen nutrition of poplar trees. Plant Biology 12 (2): 275-291. - doi: 10.1111/j.1438-8677.200 9.00309.x

Sadras VO, Rodriguez D (2010). Modelling the nitrogen-driven trade-off between nitrogen utilisation efficiency and water use efficiency of wheat in eastern Australia. Field Crops Research 118: 297-305. - doi: 10.1016/j.fcr.2010.06. 010

Schildbach M, Wolf H, Hartmann K (2012). Untersuchungen zur abiotischen Resistenz schnellwachsender Baumarten [Analysis of abiotic resistance of fast growing trees]. In: "Züchtung und Ertragsleistung schnellwachsender Baumarten im Kurzumtrieb" [Breeding of fastgrowing tree species]. Nordwestdeutsche Forstliche Versuchsanstalt, Hann. Münden, Germany, vol. 8, pp. 237-257. [in German] Shortall OK (2013). "Marginal land" for energy crops: exploring definitions and embedded assumptions. Energy Policy 62: 19-27. - doi: 
10.1016/j.enpol.2013.07.048

Street NR, Skogström O, Sjödin A, Tucker J, Rodríguez-Acosta M, Nilsson P, Jansson S, Taylor $G$ (2006). The genetics and genomics of the drought response in Populus. The Plant Journal 48 (3): 321-341. - doi: 10.1111/j.1365-313X.2006.02 864.x

Thieret JW (1982). Trees and shrubs hardy in the British Isles. Economic Botany 36 (3): 273.

Tschaplinski TJ, Tuskan GA, Gebre GM, Todd DE (1998). Drought resistance of two hybrid Populus clones grown in a large-scale plantation. Tree Physiology 18: 653-658. - doi: 10.1093/tree phys/18.10.653

Viger M, Taylor G (2012). Adaptive mechanisms and genomic plasticity in drought tolerance identified in a European population of Black
Poplar (Populus nigra L.). In: Proceedings of the Conference "Plant and Animal Genome XX Conference2. San Diego (CA, USA) 14-18 Jan 2012, abstract book, paper no. 2689. [online] URL: http://pag.confex.com/pag/xx/webprogram/Pa per2689.html

Vitousek PM, Gerrish G, Turner DR, Walker LR, Mueller-Dombois D (1995). Litterfall and nutrient cycling in four Hawaiian montane rainforests. Journal of Tropical Ecology 11: 189-203. - doi: 10.1017/S0266467400008634

Wetterstation Goettingen (2014). Archiv 20112014. Goettingen, Germany, web site. [online] URL: http://www.wetterstation-goettingen.de/ wetterarchiv-2014.html

Zalesny Jr RS, Cunningham MW, Hall RB, Mirck J, Rockwood DL, Stanturf JA, Volk TA (2011).
Woody biomass from short rotation energy crops. Sustainable production of fuels, chemicals, and fibers from forest biomass 1067: 2763. - doi: 10.1021/bk-2011-1067.choo2

\section{Supplementary Material}

Fig. S1 - The block design of Max1 (blue color) and $\mathrm{H}_{2} 75$ (white color) plantation. Each cell represents one plant. The left box with red edge corresponds to deep soil; the right box with red edge corresponds to shallow soil.

Link: Euring_2016@supplo01.pdf 